\title{
Feathered fossils cause a flap in museums
}

Rex Dalton, San Diego

The mysterious background of Chinese dinosaur fossils in an exhibition is posing awkward questions for North American museums, which want to ensure that only properly obtained specimens are displayed.

Experts and Chinese officials are worried that some of the 34 fossils in the exhibit currently on show at the San Diego Natural History Museum - may have been smuggled out of China and sold in the underground trade. The Royal Ontario Museum in Toronto is investigating the allegations before deciding whether to display the feathered specimens next year.

Stephen and Sylvia Czerkas, the Utahbased married couple who compiled the exhibit, say they have permission to borrow the fossils from China, and will return them when the exhibit has finished touring. "We did not purchase them," says Sylvia Czerkas.

But Ji Qiang, head palaeontologist at the Institute of Geology in Beijing, China, thinks that about a dozen of the specimens may be in the United States improperly. When he first saw the fossils three years ago at the Czerkases' Dinosaur Museum in Blanding, Utah, Ji says he identified three of them as being of "great scientific value".

After discussions with the Czerkases, Ji says, he assigned specimen numbers to the three most desired fossils for his geological institute.

Ji says he is in no doubt that the specimens were allowed to leave China illegally. "The problem is, how do I do research on them?" he asks. "And how can I get the specimens?"

Sylvia Czerkas says that all of the specimens are to be returned to China in 2007 under a 2001 loan agreement reached with officials of Liaoning province in northeast China, where fabulous fossils from 120 million years ago have been found.

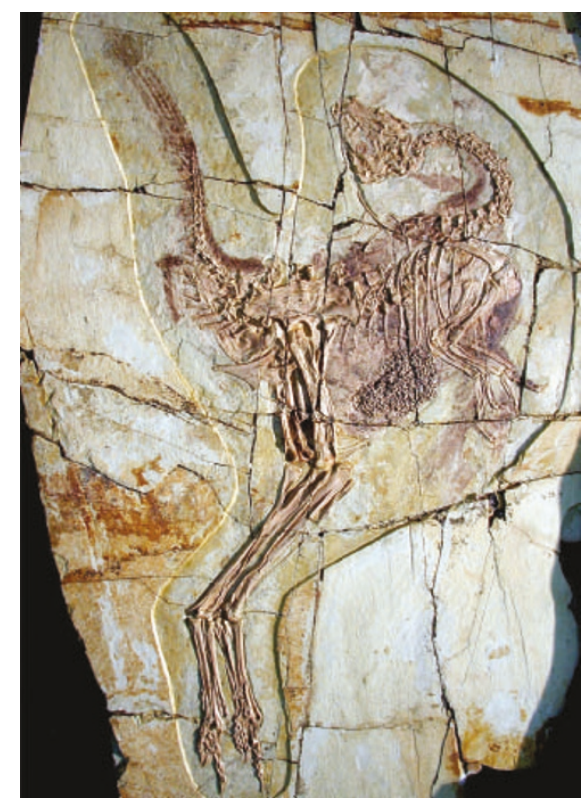

Early birds? Feathered dinosaurs such as Caudipteryx provide clues to how flight evolved.

When informed that Ji had described the specimens as "illegal", Czerkas responded: "That is not true."

Stephen Czerkas is an artist who is selftaught in palaeontology, and Sylvia serves as museum curator. Five years ago, the couple were involved in an international controversy after their museum bought a fossil, called Archaeoraptor, for $\$ 80,000$ at a fossil show in Tucson, Arizona.

The fossil appeared in National Geographic magazine after failed attempts to publish it in both Nature and Science. But it was subsequently found to be a forged composite from different species (see Nature 410, 539; 2001), put together in China to resemble a 'missing link' between dinosaurs and birds. It was returned there in 2000, and segments later generated scientific papers by Chinese authors and by Stephen Czerkas.

The Czerkases have been offering their latest exhibit, called "Feathered Dinosaurs and the Origin of Flight", to interested museums for two years. The museums pay a set fee for the display. Dinosaur exhibits are in demand because they bring in the crowds, but some museums say that they have declined to take the exhibit.

At the Natural History Museum of Los Angeles County, which didn't consider the Czerkas exhibit, palaeontology curator Luis Chiappe says that specimens that come from the underground trade should not be displayed, even if they are to be repatriated. Exhibiting them promotes commerce in illegal specimens, he says, and encourages the removal of more palaeontological treasures.

In its first showing outside their own museum, the exhibit opened a seven-month run in February at the San Diego museum. Palaeontologist Mick Hager, the museum's executive director, says he believes that the specimens are important and should be displayed. He adds that he accepts the Czerkases' assurances that the specimens are legally loaned and will be returned to China.

Two Chinese officials from Liaoning attended the opening, but the Czerkases refused requests to make them available for interview. Ji was billed as due to attend, but chose not to do so.

Mark Engstrom, the Royal Ontario's vicepresident for collections, says it has opened an investigation into the fossils' recent history. The museum has agreed to bring the fossils to Toronto in the spring of 2005, but Engstrom says his facility will not fully commit until more is known about them. "It is up to the museum community to police itself," he says. "We have to determine if the material can be legally imported to Canada."

\section{Top job at NSF on hold until after US elections}

Geoff Brumfiel, Washington

Prospects are fading that a director for the US National Science Foundation (NSF) will be named any time this year, officials familiar with the search say.

The top slot at the research agency has been filled on an interim basis by Arden Bement, head of the National Institute of Standards and Technology, since Rita Colwell vacated it on 21 February (see Nature 427, 665; 2004). On 26 February, John Marburger, head of the White House Office of Science and Technology Policy, told a congressional hearing that he was "very optimistic" that a replacement could be found in a matter of months.

But officials close to the search process think that the frenzy of election year will make this unlikely. "The longer it takes them to announce a candidate, the less likely it is they can get him or her confirmed," says Joel Widder, a lobbyist with Lewis-Burke Associates in Washington and former head of legislative affairs at the NSF.

The gap leaves plenty of time for science lobbyists to speculate on who Colwell's eventual replacement will be. One name said to be in the frame, if President Bush is re-elected in November, is Raymond Bowen. A mechanical engineer at Texas A\&M
University in College Station, Bowen has been a member of the National Science Board - the presidentially appointed body that oversees the NSF - since 2002.

Bowen served as president of Texas A\&M from 1994 to 2002 . He worked at the NSF as head of its mechanical-engineering division from 1982 to 1983 , and as deputy chief of its engineering directorate from 1990 to1991.

Bowen says he has not been officially approached for the job, and refuses to say whether, if offered, he would take it. "I am deeply involved in preparing an exam for a class that needs to be challenged in ordinary differential equations," he told Nature. 